\title{
Tiede tarvitsee liennytystä
}

YK:n tietojen mukaan kolmannes maailman valtioiden tutkimusmäärärahoista käytetään sotilaallisiin tarkoituksiin. Luonnontieteiden ja tekniikan tutkijoista $40 \%$ toimii sotilaallisluonteisissa tehtävissä. Osuus on niin suuri, että varustelu lyö välttämättä leimansa tieteen koko kuvaan.

Eräät tärkeät keksinnöt ovat syntyneet sotilaallisen tutkimuksen piirissä. Tämä saattaa synnyttää illuusion, että asevarustelu stimuloisi tieteen kehitystä. Todellisuus on kuitenkin toisenlainen. Sotatekninen tutkimus on hyvin erikoistunutta sovellettua tutkimusta, tuotekehittelyä, ja selvitysten mukaan vain $\mathrm{n}$. $20 \%$ :lla sen piirissä saaduista tuloksista on edes jotain merkitystä sota-alan ulkopuolella.

Asevarustelu määrää monella tärkeällä tieteen ja tekniikan alalla tutkimuksen suuntaamisen, julistaa tulokset salaisiksi, militarisoi tieteellisen organisaation ja vääristää tieteen humaanin luonteen sekä objektiivisesti että tutkijoiden tietoisuudessa.

Militarismin vaikutukset koskettavat myös suomalaisia tutkijoita jo yksin siitä syystä, että tutkimus on nykyisin kansainvälistä. Sitäpaitsi Suomessakin uhrataan asehankintoihin miljardeja; Suomessakin lähes 1000 tutkijaa toimii asekehittelyn piirissä.

Idän ja lännen suhteisiin on viime aikoina pyritty lyömään kuilua. Liennytys yritetään peruuttaa ja palata voimapolitiikan ja konfrontaation aikaan. Myös tieteellistä vaihtoa ja yhteistyötä on vaikeutettu poliittisilla boikottikampanjoilla ja käyttämällä tieteellisiä foorumeita liennytyksen vastaisen mielialan lietsomiseen.

Tällä pyritään toisaalta painostamaan sosialistisia maita, toisaalta raivaamaan tietä su- vaitsemattomille ja militaristisille asenteille läntisten tiedemiesten keskuudessa. Kilpavarustelun järjettömyys ja vahingollisuus koetetaan saada peittymään ja tutkijoiden vastalauseet vaimenemaan.

Nykyiselläänkin tieteellisen vaihdon ja yhteistyön vähäisyys kapitalististen ja sosialististen maiden välillä vaikeuttaa tieteen kehitystä. Myös Suomen ja Neuvostoliiton tieteellinen yhteistyö on monilla aloilla mahdollisuuksiin ja tarpeisiin nähden suppeaa.

Suomalaiset tutkijat ja tieteelliset yhteisöt voivat esittää merkittävää osaa raja-aitojen murtamisessa sekä kansainvälisellä toiminnallaan että kehittämällä omalta osaltaan Suomen ja Neuvostoliiton tieteellisiä yhteyksiä.

Asevarustelun lopettaminen edellyttää runsaasti tutkimustyötä, miten armeijoita pienennetään, miten sotateollisuus muutetaan hyödylliseksi teollisuudeksi, miten ihmisiä kasvatetaan rauhaan ja kansainvälisyyteen. Tässä on laaja ongelmakenttä; kutsukaamme sen tutkimista rauhantutkimukseksi. Rauhantutkimus edellyttää avointa ja tieteellistä lähestymistapaa, ja se tarvitsee tuekseen monien eri tieteenalojen panosta.

Maatamme valmistetaan kriisien ja sodan varalta, mutta rauhantutkimus kärsii varojen puutteesta. Tampereen Rauhan- ja konfliktintutkimuslaitoksen voimavaroja on huomattavati lisättävä. Rauhantutkimukseen liittyviă projekteja olisi syytä käynnistää myös korkeakouluissa ja Suomen Akatemiassa.

Suomalaiset tutkijat - toimintaan rauhan ja kansainvälisen yhteistyön puolesta!

Tutkijaliiton 3. liittokokous 23. 11. 1980 